Article

\title{
Hotels as Critical Hubs for Destination Disaster Resilience: An Analysis of Hotel Corporations' CSR Activities Supporting Disaster Relief and Resilience
}

\author{
Sarah Dobie ${ }^{1, * \mathbb{D}}$, Jennifer Schneider ${ }^{1, *}$, Muhammet Kesgin ${ }^{2}$ and Rick Lagiewski ${ }^{2}$ \\ 1 Rochester Institute of Technology, Collaboratory for Resiliency and Recovery, Rochester, NY 14623, USA \\ 2 Rochester Institute of Technology, Department of Hospitality and Tourism Management, \\ Rochester, NY 14623, USA; mxkism@rit.edu (M.K.); rxlisr@rit.edu (R.L.) \\ * Correspondence: sad6843@rit.edu (S.D.); jlwcem@rit.edu (J.S.)
}

Received: 15 August 2018; Accepted: 1 October 2018; Published: 18 October 2018

check for updates

\begin{abstract}
Disaster management has begun to examine the unique role of the private sector in disaster relief. The hotel and lodging industry is an especially critical infrastructure for community disaster relief and resilience, providing many lifeline services in addition to core skills and competencies contributing to the community's social and human capital. Social and human capital empower the community to better cope with disturbance, and companies' efforts to build social and human capital are often tied to their corporate social responsibility (CSR) management systems. A framework was developed to evaluate the management system maturity of the hotel and lodging industry's CSR management for disaster relief and resilience. An analysis of three hotel and lodging corporations was performed to understand the current state of the industry. While many hotel properties are engaging in CSR activities during disaster relief, the analysis revealed that corporate management systems have room for maturation and growth to support the resilience of their community.
\end{abstract}

Keywords: hotel; disaster relief; resilience; sustainable development; corporate social responsibility; indicators; metrics; framework; management systems

\section{Introduction}

Natural disasters are becoming increasingly frequent and severe, posing a major threat to the human population [1,2]. The total cost of disasters from 1980 to 2017 has exceeded \$1.5 trillion [3]. In 2017 alone, the United States had 16 weather and climactic disaster events that resulted in at least $\$ 1$ billion in losses, amounting to over $\$ 300$ billion in losses [3].

Communities have started to focus on fostering resilience to prepare for responding and recovering from disasters. There are many accepted definitions for resilience. The Community and Regional Resilience Institute (CARRI) defines resilience as, "to anticipate risk, limit impact, and bounce back, [using] survival, adaptability, evolution, and growth in the face of turbulent change" [4]. The Rockefeller Foundation, as the founder of 100 Resilient Cities, provides another definition of resilience in urban areas: "the capacity of individuals, communities, institutions, businesses, and systems within a city to survive, adapt, and grow no matter what kinds of chronic stresses and acute shocks they experience" [5]. Similarly, the International Organization for Standardization (ISO) defines resilience as "adaptive capacity of an organization [or community] in a complex and changing environment" [6]. All three definitions capture the concept that resilience means that the community must have the capacity to not only survive and cope with disasters, but also to adapt and continue to thrive. 
In order to create this capacity, communities have started to focus on building community capital, particularly social and human capital, which empower the community to better respond and recover from disasters. Social capital can be summarized as, "the set of relationships that have developed around shared values, norms, and trust" [7]. Human capital is comprised of education and skills, as well as a "level of personal spirituality or religious affiliation ... basic moral character, emotional stability, and physical health" [7]. A focus on building social and human capital proactively addresses root causes of vulnerability and develops assets that can be leveraged when crises arise [8].

Conventional activities have focused on controlling climate impacts through engineering; however, these controls can be overpowered, and the consequences of failed controls may be costly. Thus, it is important to supplement these controls by enhancing social and human capital. These forms of capital improve the community's education and awareness and strengthen social networks, contributing to community competence and cohesion, which are vital to community resilience.

The role of the private sector in community disaster relief and resilience is expanding, transitioning from traditional philanthropic financial contributions to innovative applications of business' core skills and competencies to improve disaster response and recovery (DRR) operations and community resilience $[9,10]$. The hotel and lodging industry will be especially crucial in community response and recovery, as many of these properties are located in coastal regions that are disaster-prone, are a crucial component of tourist destinations' economies, and often act as hubs for resilience during disasters [11-13].

Many companies contribute to disaster relief as part of their corporate social responsibility (CSR) programs [14]. CSR is most frequently defined as [15] "a concept whereby companies integrate social and environmental concerns in their business operations and in their interaction with their stakeholders on a voluntary basis" [16]. CSR is based on the premise that businesses have responsibilities to the community as corporate citizens, which include generating profits, complying with laws and regulations, conducting business in an ethical manner, and giving back to the community through philanthropy [17]. Over time, small bouts of philanthropy have grown into longer-term initiatives that are aimed at addressing societal needs and challenges [18,19].

Businesses have assisted in disaster relief as part of their CSR programs for many years, consisting primarily of financial contributions. Companies would provide cash donations and hold fundraisers to assist humanitarian relief organizations. While these traditional types of contributions are encouraged, the expectation of businesses' contributions is growing, and businesses are being encouraged to engage in disaster relief in new, innovative ways $[9,10,20,21]$.

The private sector has the ability to leverage core skills and competencies in unique ways to provide disaster relief to affected communities. In a survey conducted by Business in the Community (BITC), $25 \%$ of businesses reported that they have provided non-financial disaster relief contributions, such as deploying trained employees to support DRR operations, assisting with solving logistical problems for DRR operations, and volunteering to support rebuilding homes and critical infrastructures [9]. Businesses are finding innovative ways to assist in disaster relief throughout the process - preparedness through recovery - both in their operations and in the community.

CSR management is shifting focus from merely mitigating negative impacts to shared value creation through the co-creation of social value through business activities that address societal needs and challenges. Companies may empower the community to address these challenges through contributions to social and human capital. For example, Marriott has set a goal for $25 \%$ of all reported volunteer hours to be skill-based, leveraging the hotel employees' core skills and competencies to support community service projects and disaster relief [22]. Another example is Hilton's 2030 goal to double its investment in social impact and reduce its environmental footprint by half through responsible hospitality practices [23].

Many companies publish CSR reports that summarize activities and provide performance measures and outcomes for the various dimensions of their CSR programs. Contributions to disaster relief and resilience are primarily reported in terms of financial contributions. However, these reports 
often fail to account for the social value creation resulting from their contributions, and do not provide comprehensive information about non-financial contributions, i.e., contributions addressing societal needs and challenges.

Identifying the value created through financial and non-financial contributions can be challenging, as social and human capital are not a tangible object or system that is easily quantified [19]. Social and human capital contribute social value, which extends beyond their economic value and must be evaluated in order to understand their true value of CSR contributions to disaster relief and resilience.

Some sectors, such as professional services, media and technology, construction and materials, healthcare and pharma, and transportation and logistics, have begun to conduct case studies that examine non-financial contributions [21]. However, these case studies do not comprehensively examine contributions across a given sector. Additionally, the private sector's contributions are primarily captured in non-academic press, such as company and foundation reports and newspaper articles.

Understanding the value of these contributions is an essential step for understanding the critical contributions of the hotel and lodging industry to community disaster relief and resilience. Disaster management resources may be limited relative to the events and needs, and community resilience hubs must be prioritized. During a disaster, the hotel and lodging industry becomes critical infrastructure that provides shelter and nearly all lifeline services to community members and disaster response and recovery (DRR) workers. Additionally, the industry applies "soft skills" to comfort community members, coordinate relocation during evacuation, and supports the reconnection of family and friends [24]. This is a further manifestation of the role that the industry plays pre-disaster to proactively build social and human capital, contributing to education and job opportunities and engaging in activities addressing societal needs and challenges.

This paper develops and pilots a methodology to assess the maturity of the disaster relief and resilience dimension of CSR management systems in the hotel and lodging industry, specifically focusing on contributions to social and human capital. A five-level indicator framework was created to assess CSR management system maturity, and metric sets were developed for application of the framework specifically to the hotel and lodging industry. The metric sets include measures that assess the management system's ability to drive continuous improvement, including performance metrics to assess the social value creation of CSR contributions. These metrics can be applied in two ways: (1) hotel and lodging corporations can use them to structure their CSR management systems and assess the social value of their contributions, and (2) an analysis can be performed to assess the maturity of hotel and lodging corporations' CSR management systems. To demonstrate how metrics can be applied to maturity assessment, the metric sets were used to analyze the maturity of the three largest hotel corporations' CSR management systems for disaster relief and resilience, providing insight into the current state of CSR management across the hotel and lodging industry.

\section{Materials and Methods}

The methodology for this paper consists of four parts. First, the definition of social value and current methodologies for social value are explored to scope the framework. Second, a literature review was performed to develop an indicator framework to summarize the private sector's CSR contributions to disaster relief and resilience. Metric sets were then developed for structuring and evaluating the performance of hotel and lodging corporations' CSR management for disaster relief and resilience. Finally, three hotel and lodging corporations are analyzed using the industry-specific framework in order to provide insight into the maturity of the hotel and lodging industry.

In a socially driven methodology, there is often a problem with scoping the analysis. Thus, there was a need in this paper for an extensive review of background and methodology. The paper limited the scope to those social operational constructs that were indicative of the hotel and lodging industry. In this case, we began our efforts by analyzing the three largest hotel and lodging corporations. 


\subsection{Defining and Measuring Social Value}

As business' CSR management systems mature, the literature shows that businesses expand performance evaluation beyond their operations to encompass the performance of the integrated community-organizational system [25]. For example, as in other business sectors, if a hotel business worked to improve their CSR performance during normal operations, the hotel business would first work to improve their performance at the property level, focusing on the improvement of their social and environmental impact within their premises. This may include initiatives for energy and water efficiency, green cleaning programs, employee wellness programs, and employee career development programs. Next, the hotel may expand its focus to procurement, such as increasing spend locally and purchasing products with sustainability certifications. Finally, the hotel business would align and integrate its management with community sustainable development efforts, collaborating on initiatives and working to address community social and environmental issues that also benefit the business $[25,26]$.

Many companies' CSR programs have also shifted their focus to shared value creation: the co-creation of social and economic value through business activities. Socially valuable activities can be defined as activities that address societal needs and challenges, such as improving food security and nutrition, education, and public health and safety $[27,28]$. Many of these activities include contributions to social and human capital.

In the context of disaster relief and resilience, social value would be co-created when activities aiding in hotel disaster management also contribute to community recovery and resilience or address other societal needs and challenges. Other socially valuable activities may focus on building community capital, particularly social and human capital, to proactively improve community and organizational disaster resilience.

Identifying and quantifying the social value of CSR activities is challenging, as the impacts are often not tangible [19]. Currently, a comprehensive framework of metrics for evaluating the economic and social impact of the hotel sector activities does not exist. However, some general methodologies have been developed for quantifying impacts of CSR activities that can be applied to assess the social value of the hotel and lodging industry's CSR activities supporting disaster relief and resilience.

One proposed method for measuring the social value of activities is Social Return on Investment (SROI). SROI essentially uses a lifecycle assessment to quantify the project costs and revenue produced, and assign a monetary value to both the positive and negative social impacts. SROI is calculated by adding the revenue produced and monetary value of positive social impacts, and then subtracting the project costs and monetary value of negative social impacts [29].

The World Bank developed another method for quantifying social value creation as part of its Social Capital Initiative that looks at non-financial indicators. Due to the difficulty in measuring social capital, proxy indicators can be developed to measure the benefits from social value creation [19,30]. Indicators are specific to each locality and sector, and therefore are developed on a case-by-case basis to align with each activity [19].

The World Council for Sustainable Development developed a third method for quantifying social value creation that is a combination of the previous two methods. The direct and indirect impacts of each business activity are identified, the economic value of the activity is measured, and additional proxy indicators are developed to measure direct and indirect impacts [31]. For example, if roads and bridges are constructed, there are a number of impacts, such as increased migration and traffic congestion. The new transportation infrastructure may increase the ease of migration and reduce traffic congestion, which are outcomes that the community may find socially valuable. Proxy measures can be developed to assess these social impacts resulting from the project, and the economic value of financial contributions can be measured. Social and economic metrics can be examined in tandem to evaluate the project's performance [31].

The indicator framework developed by this paper uses the World Council for Sustainable Development method, combining economic metrics and other proxy measures for social impacts 
to assess projects. This method can then be used to plug into a SROI calculation. The economic value of social impacts can be calculated using the proxy measures. This approach was favored since the SROI method may not be practical for companies with limited resources and immature management systems that are unable support comprehensive data collection. Thus, the SROI method may be better explored after CSR management systems become more mature [32]. Since the hotel and lodging sector is inherently a service and experience business, any index framework that is developed for measurement will then have a large reliance on social impact contributions and indicators.

\subsection{Developing a Framework to Assess the Disaster Relief and Resilience Dimension of CSR Management}

A literature review was performed to summarize the disaster relief and resilience CSR activities and metrics of the hotel and lodging industry, as well as corporate leaders in other industries. The literature review included academic journals, corporate reports and media, and other non-academic press. Sources from other non-academic press were gathered from hotel foundation and association websites and hotel news sources.

Google Scholar was used to search for journal articles. Books were excluded, and the search was sorted by relevance. The literature review examined the 15 most relevant journal articles for the hotel and lodging industry's CSR contributions to disaster relief and resilience, as well as the 15 most relevant journal articles for the private sector's CSR contributions to disaster contributions to disaster relief and resilience. Corporate reports and media were pulled from corporate websites for the major international hotel and lodging companies from the past two years, including but not limited to the three corporations examined in the analysis. Additionally, reports summarizing the private sector's contributions to disaster relief and resilience were examined to supplement hotel and lodging industry reports and media. Hotel and lodging industry non-academic press websites were found using a web search by relevance. Since there were a limited number of articles that appeared on these websites, any relevant articles were included.

CSR activities and metrics for disaster relief and resilience were categorized by types of contributions based on categories developed by the Business in the Community (BITC) $[9,10]$ and the United Nations Office for the Coordination of Humanitarian Affairs (OCHA) [20,21]: financial contributions to DRR, the donation of commercial products and services to DRR, the deployment of employees for DRR, and community capital building for disaster resilience.

Partnerships and relationships are generally considered a type of social capital that would be nested under community capital building; however, this was separated and incorporated into another category: integrated, resilient, and sustainable systems. Activities and metrics were designated as part of integrated, resilient, and sustainable systems, since they are either initiatives that have co-ownership by the company and community, or metrics that evaluate how the business is actually impacting the community. This is the next step beyond conventional activities and metrics for community capital building, and thus, there was an additional category created.

Each category was divided into key themes. Themes were further refined and supplemented through analysis of the literature. Figure 1 shows a summary of the frequency of themes for socially valuable activities and metrics related to disaster relief and resilience that were found in the literature review.

The literature review pulled a total of 162 activities and metrics from 60 sources; $7 \%$ were academic journals, $52 \%$ were corporate reports and media, and $41 \%$ were other non-academic press $[9,10,14,20-22,33-83]$. From these sources, the types of CSR activities and metrics reported by the hotel and lodging industry were identified and sub-divided into themes.

As for the frequency of activities and metrics, $24 \%$ were financial contributions to DRR, $19 \%$ were donated commercial products and services for DRR, $8 \%$ involved the deployment of employees for DRR, 33\% were contributions to community capital for disaster resilience, and $17 \%$ were contributions to integrated, resilient, and sustainable systems. 


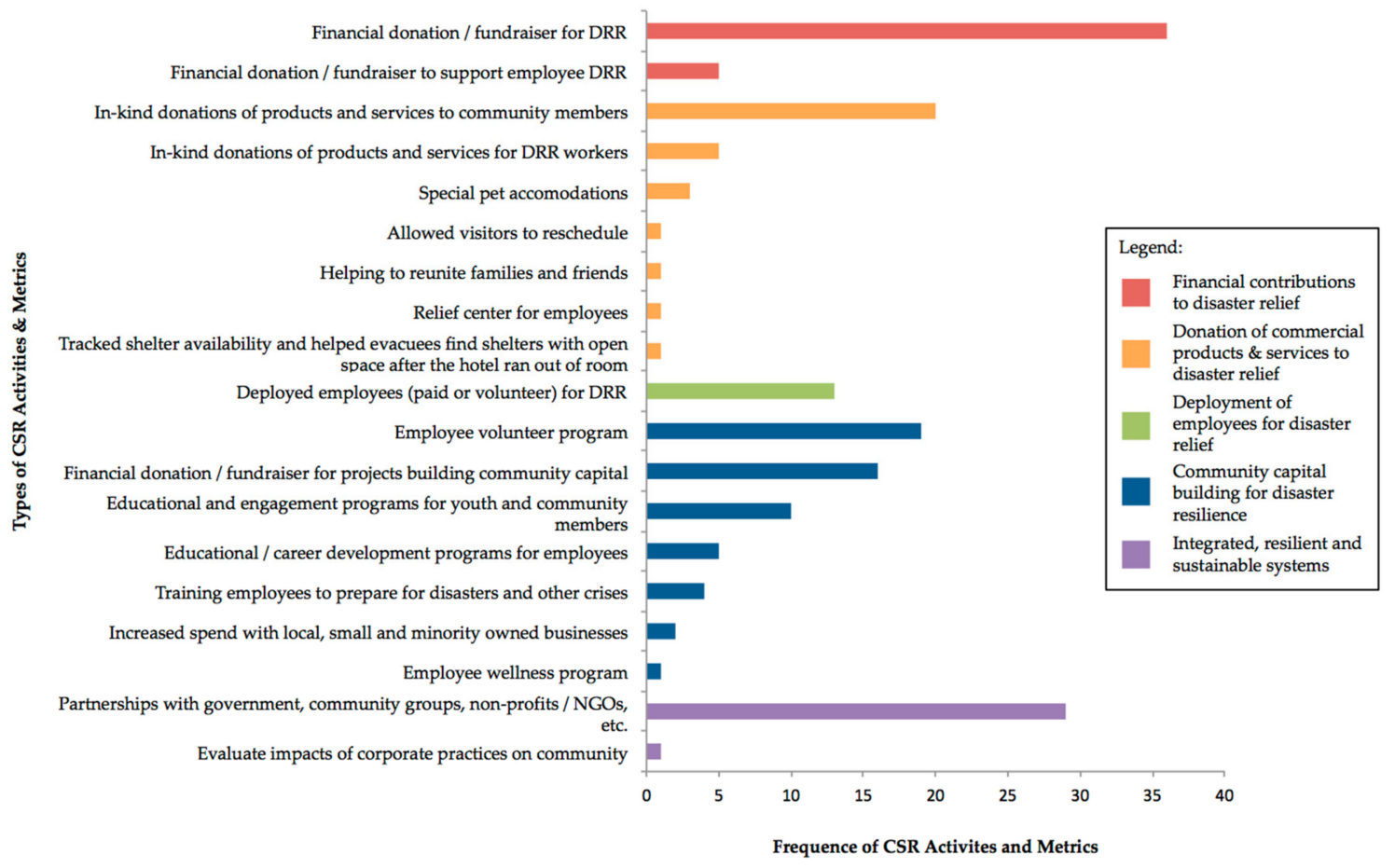

Figure 1. Frequency of socially valuable activities supporting disaster relief and resilience.

From this literature review and existing methodologies for social value assessment, a five-level indicator framework was developed based on the Lowell Sustainable Production System framework developed by Velva and Ellenbecker [25]. Sustainability and resilience share many parallels and are often interdependent, allowing for the Lowell Sustainable Production System framework to be adapted for use in assessing resilience. Figure 2 shows the five-level indicator framework for assessing the private sector's CSR contributions to disaster relief and resilience.

Level one includes financial contributions for disaster relief. Level two consists of commercial products and services donated by the company for disaster relief. Level three is the deployment of employees (paid or volunteer) to assist in disaster relief, including both skilled and unskilled activities supporting humanitarian assistance and DRR operations. For the purposes of this paper, skilled deployment includes activities that leverage core skills and competencies of hospitality workers to contribute to disaster relief.

Level four includes activities that have been undertaken to proactively build the community's capacity, typically occurring as part of disaster preparedness. This level encompasses activities and metrics that proactively contribute to building the community's assets, i.e., community capital, thereby improving the community's adaptive capacity. For example, a company could establish a scholarship to support hospitality and tourism students, start programs to promote employee career development, or deploy employees to assist with protecting and preserving tourism assets, such as cleaning and maintaining a park that is a popular tourist attraction.

Level five includes integrated, resilient, and sustainable systems resulting from hotel disaster relief and resilience CSR activities. Integrated systems are the combined community-organizational management systems. These systems occur when the community and organizations collaborate on the planning and implementation of disaster relief and resilience efforts. Additionally, organizations form part of an integrated system that would measure their social impact on the community and evaluate the connection between organizational activities and community well-being. 


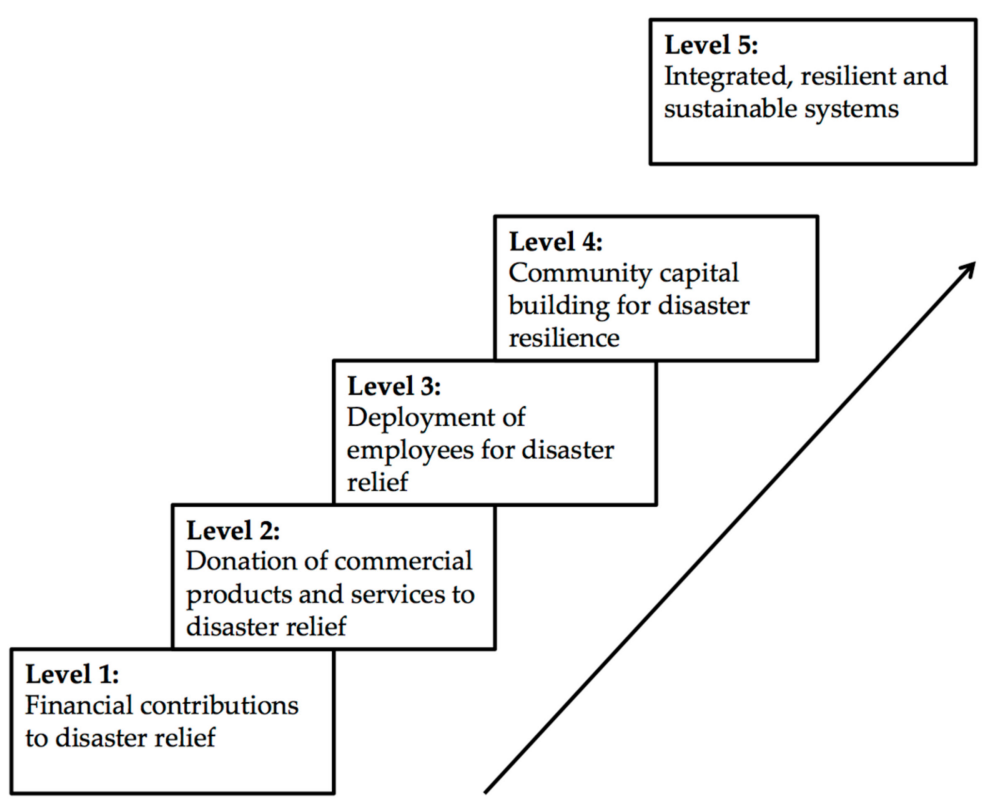

Figure 2. Five-level indicator framework to assess the disaster relief and resilience dimension of corporate social responsibility (CSR) management systems.

Tiered indicator frameworks can be used to quantify the overall resilience of the community or critical infrastructure by aligning metrics with each level [26,84-86]. To adapt the indicator framework for use by the hotel and lodging industry, metrics were developed to align with the industry's activities based on the literature review, including activities reported at the property level and the corporate level.

Management systems drive continuous improvement through application of the Plan-Do-Check-Act (PDCA) process. Metrics allow the framework to be applied, while management system design and implementation drive the continuous improvement of the management system $[26,84]$. As the organization works to measure higher-level metrics, more initiatives and processes must be implemented to support performance evaluation, which ideally results in the improved performance of the collective system [84,87].

Metrics can act as proxies for management system maturity. Lagging metrics indicate that the company is working to minimize the negative impacts of its operations, and leading metrics indicate that the company is taking proactive action to address risks-in many cases beyond operational boundaries-and improve its management system.

Two sets of metrics were developed to create a framework specifically for assessing the disaster relief and resilience dimension of the hotel and lodging industry's CSR management systems. The first set of metrics can be used to analyze corporate vision/policy statements and goals, providing insight into the planning portion of the PDCA process. The second set of metrics includes the performance measures that are tracked and reported by the organization, providing insight into the Do-Check-Act portions of the PDCA process. If a corporation is reporting the metrics, then implementation (Do) and performance evaluation (Check) have occurred, and when metrics examine changes in performance over time, it is likely that evaluation has led to the company making changes to the management system to improve performance (Act).

Figure 3 demonstrates a metric set for analyzing the corporate vision/policy statements and goals of the hotel and lodging industry. Key themes that were found in the literature review were used as leading metrics to analyze vision/policy statements and goals. Some themes were grouped together, as vision/policy statements and goals may not be specific to types of activities. For example, a company may set a goal to increase the amount of in-kind donations, but the company may not specify the types of in-kind contributions. An analysis of vision/policy statements and goals provides 
insight into the level of top management commitment and aspirations for the corporation in its disaster relief efforts and contributions to resilience through building community social and human capital.

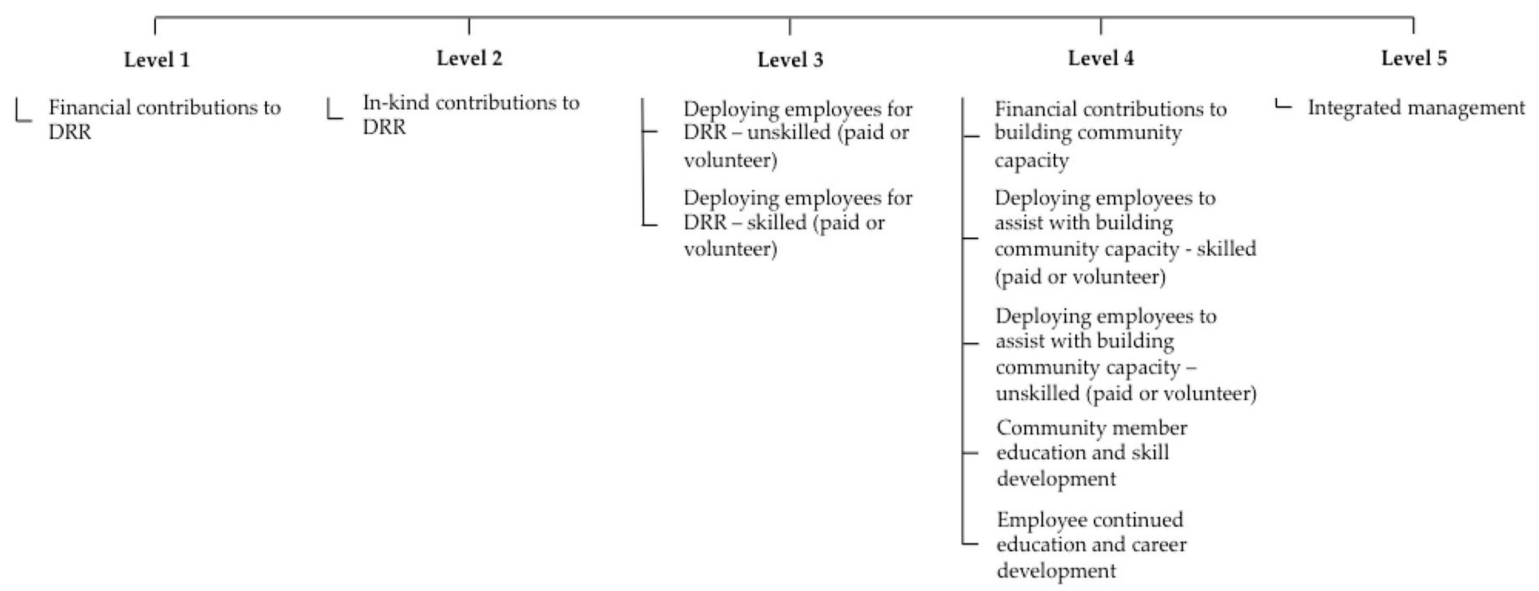

Figure 3. Tiered indicator framework to evaluate the disaster relief and resilience dimension of CSR vision/policy statements and goals.

Figure 4 shows a second metric set to assess the management system maturity for performance evaluation through the examination of metrics tracked by companies. These metrics summarize the specific activities and metrics reported by hotel and lodging companies. For activities that are not aligned with metrics in the literature, metrics were developed to evaluate performance in terms of the social and economic value created by the activity, similarly to the World Council for Sustainable Development method for assessing social value.

\begin{tabular}{|c|c|c|c|c|}
\hline & 1 & & & \\
\hline Level 1 & Level 2 & Level 3 & Level 4 & Level 5 \\
\hline $\begin{array}{l}\$ \text { donated to DRR through: } \\
\text { cash donations, matching } \\
\text { program, fundraisers, and } \\
\text { community grants } \\
\# \text { of communities / people } \\
\text { impacted by financial } \\
\text { contributions } \\
\# \text { of customer loyalty points } \\
\text { donated } \\
\# \text { of grants given out } \\
\# \text { of fundraiser events held / } \\
\# \text { of people that attended } \\
\text { fundraiser events }\end{array}$ & \begin{tabular}{|l} 
Economic value of goods \\
and services provided to \\
guests for DRR (discounted \\
room rates and free meals, \\
electricity, water, wi-fi, etc.) \\
\# of goods and services \\
provided / \# of \\
- communities / people \\
provided with goods and \\
services \\
\# of employees assisted \\
through donated goods and \\
services \\
\# of DRR workers assisted \\
through donate goods and \\
services \\
$-\quad$ \# of pets accommodated \\
Economic value of refunds \\
given to visitors \\
$\%$ of visitors refunded / \\
rescheduled rooms (1pt); \# \\
of visitors refunded / \\
rescheduled rooms (0.5pt)
\end{tabular} & 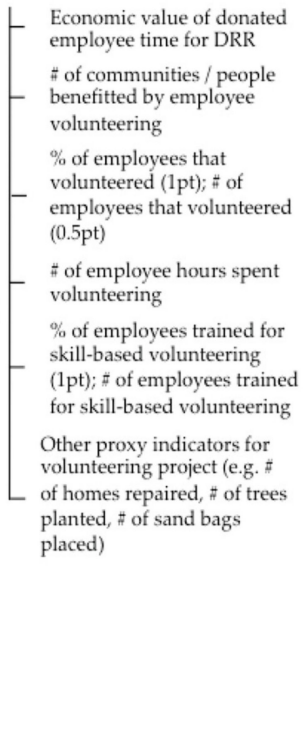 & $\begin{array}{l}\text { \$donated to projects } \\
\text { building community capital } \\
\text { (e.g. building schools, career } \\
\text { development, caring for } \\
\text { tourism assets) } \\
\text { Economic value of donated } \\
\text { products and services } \\
\text { Economic value of employee } \\
\text { volunteering } \\
\text { Economic value of career } \\
\text { development opportunities } \\
\% \text { of employees that } \\
\text { volunteered (1pt); \# of } \\
\text { employees that volunteered } \\
\text { (0.5pt) } \\
\text { \# of hours spent } \\
\text { volunteering to build } \\
\text { community capital } \\
\text { \# of communities / people } \\
\text { benefited by building } \\
\text { community capital } \\
\% \text { of employees engaged in } \\
\text { career development } \\
\text { programs (1pt); \# of } \\
\text { employees engaged in career } \\
\text { development programs } \\
\text { ( } 0.5 \text { pt) }\end{array}$ & 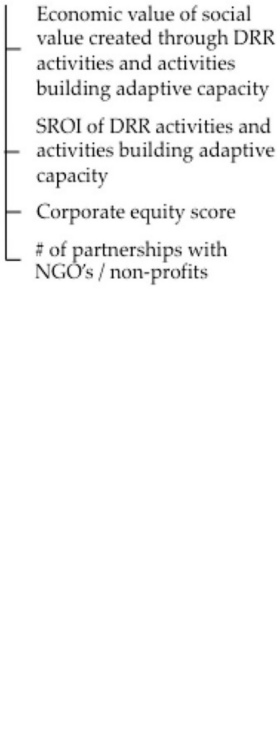 \\
\hline
\end{tabular}

Figure 4. Tiered indicator framework to examine maturity of performance evaluation of hotel corporations' CSR contributions to disaster relief and resilience.

\subsection{Analysis of Corporate Hotel Management Systems}

Three hotel and lodging corporation cases were analyzed using the two metric sets: Marriott International (Marriott), Hilton Inc. (Hilton), and the InterContinental Hotels Group (IHG). These cases 
were selected to represent the hotel and lodging industry, as they are the largest corporations internationally by number of properties and rooms according to 2016 data [88].

An analysis was performed to evaluate the maturity of the disaster relief and resilience dimension of the CSR management systems. The analysis was divided into two parts. The first part examines the CSR vision/policy statements and goals published by the companies using the first metric set. The second part used the performance evaluation framework to assess the activities and metrics reported by corporations in CSR reports and news articles using the second metric set.

This analysis provides an understanding of whether the management system is immature, merely contributing the bare minimum to disaster relief, or if the management system is more mature, adopting an integrated approach toward fostering disaster resilience and sustainability.

Maturity was calculated using the method developed by Schneider et al. [85], which developed a quantitative method that aligns metrics with the tiered indicator framework concept developed by Velva and Ellenbecker [25] to calculate management system maturity. Three equations developed by Schneider et al. [85] were adapted for calculating the maturity of the hospitality and tourism management systems.

Each maturity level is given a weight of one, and each metric was weighted equally within a given level. Equation (1) was used to calculate the weight of each indicator in a given maturity level $\left(W_{N}\right)$ :

$$
W_{N}=\frac{1}{\text { Number of Metrics }}
$$

Next, Equation (2) was used to calculate the weighted average (A) of each maturity level. This is calculated by dividing the score of each metric $\left(M_{N}\right)$ by $W_{N}$. Each metric received a score of $0,0.5$, or 1 . A company received the full point value if it tracked the metric at the corporate level. Half of one point (0.5) was awarded if the company tracked the activity at the corporate level, or if the company reported the metric or activity at the subsidiary level or property level. Zero points were awarded if the metric or activity was not reported at any level. For indicators that specify one point for a metric and 0.5 points for a metric variation, the company receives 0.25 points for tracking the metric variation or activity at the subsidiary level or property level.

Metrics and activities at the subsidiary level and property level are generally not coordinated efforts, and are reported in more of an ad hoc fashion. Additionally, merely reporting activities does not adequately evaluate performance. Metrics are needed to evaluate whether the activities are accomplishing the intended goals.

$$
A_{N}=\frac{\text { Score of } M_{1}}{W_{N}}+\frac{\text { Score of } M_{2}}{W_{N}}+\ldots \frac{\text { Score of } M_{n}}{W_{N}}
$$

Finally, Equation (3) is used to calculate the maturity score for the management system (S). This is calculated by summing the weighted averages.

$$
S=A_{1}+A_{2}+\ldots A_{N}
$$

The maturity scores resulting from the two metric sets can then be examined in tandem to evaluate the adequacy of management systems in driving continuous improvement, examining each step of the Plan-Do-Check-Act cycle. The first analysis examines the planning portion of the management system, and the second analysis examines the implementation and evaluation portion of the management system.

\section{Results}

\subsection{Vision/Policy and Goal Analysis}

Hotel and lodging corporations scored an average maturity score of 1.5 for the vision/policy statement and goal analysis. Table 1 shows the scoring for the analysis, and Figure 5 shows a 
comparison of the overall maturity scores and average maturity score. The analysis revealed that the hotel and lodging corporations' CSR programs are currently focusing primarily on contributions to community disaster preparedness through financial donations and volunteering. Contributions to disaster relief are currently focused primarily on financial donations.

Hotel and lodging companies have not yet taken a comprehensive look at how they can leverage core skills and competencies during disasters to contribute to community response and recovery. While companies may have tracked metrics related to leveraging core skills and competencies for disaster relief, there were not explicit vision/policy statements or goals indicating any intent to improve performance in this area.

Table 1. Scoring breakdown for the vision/policy statement and goal analysis. DRR: disaster response and recovery, IHG: InterContinental Hotels Group.

\begin{tabular}{lcccc}
\hline \multicolumn{1}{c}{ Level 1: Financial Contributions } & Marriott & Hilton & IHG & Average \\
\hline Financial donations to DRR & 0.5 & 1 & 0 & 0.5 \\
Weighted Average & $\mathbf{0 . 5}$ & $\mathbf{1}$ & $\mathbf{0}$ & $\mathbf{0 . 5}$ \\
\hline Level 2: Donated Commercial Products and Services & Marriott & Hilton & IHG & Average \\
\hline In-kind contributions to DRR & 0.5 & 0 & 0 & 0.2 \\
Weighted Average & $\mathbf{0 . 5}$ & $\mathbf{0}$ & $\mathbf{0}$ & $\mathbf{0 . 2}$ \\
\hline \multicolumn{1}{c}{ Level 3: Deployed Employees for DRR } & Marriott & Hilton & IHG & Average \\
\hline Volunteering for DRR-skilled & 0 & 0 & 0 & 0 \\
Volunteering for DRR-unskilled & 0 & 0 & 0 & 0 \\
Weighted Average & $\mathbf{0}$ & $\mathbf{0}$ & $\mathbf{0}$ & $\mathbf{0}$ \\
\hline \multicolumn{1}{c}{ Level 4: Building Adaptive Capacity } & Marriott & Hilton & IHG & Average \\
\hline Financial donations & 1 & 1 & 1 & 1 \\
Volunteering for building community capital & 1 & 1 & 1 & 1 \\
Community member education and skill development & 1 & 1 & 1 & 1 \\
Employee skill development & 1 & 1 & 1 & 1 \\
Weighted Average & $\mathbf{1}$ & $\mathbf{1}$ & $\mathbf{1}$ & $\mathbf{1}$ \\
\hline \multicolumn{1}{c}{ Level 5: Integrated, Resilient Systems } & Marriott & Hilton & IHG & Average \\
\hline Integrated management & 0 & 0 & 0 & 0 \\
Weighted Average & $\mathbf{0}$ & $\mathbf{0}$ & $\mathbf{0}$ & $\mathbf{0}$ \\
\hline Maturity Score & $\mathbf{2 . 5}$ & $\mathbf{3 . 0}$ & $\mathbf{1 . 0}$ & $\mathbf{2 . 2}$ \\
\hline
\end{tabular}

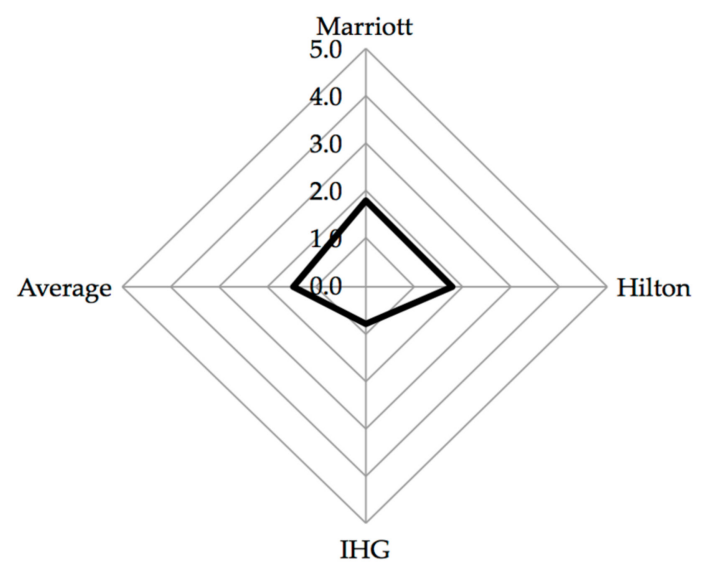

Figure 5. Maturity scores from vision/policy and goal analysis of the hotel and lodging companies.

\subsection{Metric Analysis}

These companies have a stronger focus on CSR activities that proactively build community adaptive capacity, contributing to social and human capital in order to address societal needs and challenges. However, these companies do not express any intent in working toward the 
integrated management of these issues, such as the measurement and evaluation of the impact resulting from business activities on the community and coordination of efforts with community disaster management.

Community and organizational resilience are interdependent; thus, destination resilience requires integrated management $[89,90]$. Companies may focus on contributing to community disaster preparedness, response, and recovery, but companies are not yet looking at the company and community as a collective system.

The average maturity score for the metric analysis of hotel and lodging cases was 1.4. Table 2 shows the scoring for the analysis, and Figure 6 shows a comparison of the overall maturity scores and average maturity score. Companies generally reported the monetary value financial and in-kind donations for disaster relief, as well as financial donations to projects building community capital for disaster preparedness.

However, companies were lacking metrics for the paid and volunteer deployment of employees for disaster relief. Additionally, companies did not report many proxy metrics reflecting the social impacts of their contributions. In order to understand the value of disaster preparedness, response, and recovery contributions to social and human capital, it is necessary to track proxy metrics capturing the degree that the companies impacted a societal need and challenge. This is a key step to achieving integrated, resilient, and sustainable systems.

Table 2. Scoring breakdown for the metric analysis. NGO: non-governmental organization, SROI: Social Return on Investment.

\begin{tabular}{|c|c|c|c|c|}
\hline Level 1: Financial Contributions & Marriott & Hilton & IHG & Average \\
\hline $\begin{array}{l}\text { \$ donated to DRR through: cash donations, employee matching programs, } \\
\text { fundraisers, and community grants }\end{array}$ & 1 & 1 & 0 & 0.7 \\
\hline \# of communities/people impacted by financial contributions & 0 & 0.5 & 0 & 0.2 \\
\hline \# of customer loyalty points donated & 0.5 & 0 & 0 & 0.2 \\
\hline \# of employees assisted through financial contributions & 0.5 & 0 & 1 & 0.5 \\
\hline \# of grants given out & 0.5 & 0 & 1 & 0.5 \\
\hline \# of fundraiser events held/\# of people that attended fundraiser events & 0.5 & 0 & 0 & 0.2 \\
\hline Weighted Average & 0.5 & 0.3 & 0.3 & 0.4 \\
\hline Level 2: Donated Commercial Products and Services & Marriott & Hilton & IHG & Average \\
\hline $\begin{array}{l}\text { Economic value of commercial goods and services provided to guests for DRR } \\
\text { (discounted room rates and free meals, electricity, water, Wi-Fi, etc.) }\end{array}$ & 1 & 0.5 & 0 & 0.5 \\
\hline $\begin{array}{l}\text { \# of goods and services/\# of people provided with goods and services for DRR } \\
\text { (discounted room rates and free meals, electricity, water, Wi-Fi, etc.) }\end{array}$ & 0 & 0.5 & 0 & 0.2 \\
\hline \# of employees assisted through donated products and services for DRR & 0 & 0 & 0 & 0 \\
\hline \# of DRR workers accommodated & 0 & 0 & 0 & 0 \\
\hline \# of pets accommodated during/after disaster & 0.5 & 0 & 0 & 0.2 \\
\hline Economic value of refunds given to visitors & 0 & 0 & 0 & 0 \\
\hline $\begin{array}{l}\% \text { of visitors refunded } / \text { rescheduled rooms }(1 \mathrm{pt}) ; \# \text { of visitors } \\
\text { refunded/rescheduled rooms }(0.5 \mathrm{pt})\end{array}$ & 0 & 0 & 0 & 0 \\
\hline Weighted Average & 0.2 & 0.1 & 0 & 0.1 \\
\hline Level 3: Deployed Employees for DRR & Marriott & Hilton & IHG & Average \\
\hline Economic value of donated employee time for DRR & 1 & 0 & 1 & 0.7 \\
\hline \# of communities/people benefited by employee volunteering for DRR & 0 & 0.5 & 0 & 0.2 \\
\hline $\begin{array}{l}\% \text { of employees that volunteered }(1 \mathrm{pt}) ; \text {; of employees that volunteered for } \\
\text { DRR ( } 0.5 \mathrm{pts})\end{array}$ & 0.5 & 0 & 0.5 & 0.3 \\
\hline \# of employee hours spent doing skilled and unskilled volunteering for DRR & 0 & 0 & 0 & 0 \\
\hline $\begin{array}{l}\% \text { of employees trained for skill-based volunteering }(1 \mathrm{pt}) ; \# \text { of employees } \\
\text { trained for skill-based volunteering }(0.5 \mathrm{pts})\end{array}$ & 1 & 0 & 0 & 0.3 \\
\hline
\end{tabular}


Table 2. Cont.

\begin{tabular}{|c|c|c|c|c|}
\hline $\begin{array}{l}\text { Other proxy indicators for volunteering project (e.g., \# of homes repaired, \# of } \\
\text { trees planted, \# of sandbags placed) }\end{array}$ & 0.5 & 0.5 & 0.5 & 0.5 \\
\hline Weighted Average & 0.5 & 0.2 & 0.3 & 0.3 \\
\hline Level 4: Building Adaptive Capacity & Marriott & Hilton & IHG & Average \\
\hline $\begin{array}{l}\text { \$ donated to community projects building community capital (e.g., building } \\
\text { schools, career development, caring for tourism assets-park maintenance) }\end{array}$ & 1 & 1 & 1 & 1 \\
\hline Economic value of donated goods and services & 1 & 0 & 0 & 0.3 \\
\hline Economic value of donated employee time building community capital & 1 & 0 & 0 & 0.3 \\
\hline Economic value of career development opportunities provided to employees & 0 & 0 & 0 & 0 \\
\hline $\begin{array}{l}\% \text { of employees that volunteered }(1 \mathrm{pt}) ; \# \text { of employees that volunteered } \\
(0.5 \mathrm{pts})\end{array}$ & 0.5 & 0 & 0 & 0.2 \\
\hline \# of hours spent volunteering to build community capital & 1 & 1 & 0 & 0.7 \\
\hline \# of communities/people benefited by building community capital & 0.5 & 0.5 & 1 & 0.7 \\
\hline $\begin{array}{l}\text { \% of employees engaged in career development programs }(1 \mathrm{pt}) \\
\# \text { of employees engaged in career development programs ( } 0.5 \mathrm{pts})\end{array}$ & 0.25 & 0.5 & 0.5 & 0.4 \\
\hline $\begin{array}{l}\text { Other proxy indicators for community capital projects (e.g., \# of trees planted, } \\
\text { miles of trails maintained, \% increase in student retention) }\end{array}$ & 0.5 & 0 & 0 & 0.2 \\
\hline Level 5: Integrated, Resilient Systems & Marriott & Hilton & IHG & Average \\
\hline $\begin{array}{l}\text { Economic value of social value created through DRR activities and activities } \\
\text { that build adaptive capacity }\end{array}$ & 0 & 0 & 0 & 0 \\
\hline SROI of DRR activities and activities that build adaptive capacity & 0 & 0 & 0 & 0 \\
\hline Corporate equity score & 1 & 0 & 0 & 0.3 \\
\hline \# of partnerships with NGO's/non-profits & 0.5 & 0.5 & 0.5 & 0.5 \\
\hline Weighted Average & 0.4 & 0.1 & 0.1 & 0.2 \\
\hline Maturity Score & 2.2 & 1.0 & 1.1 & 1.4 \\
\hline
\end{tabular}

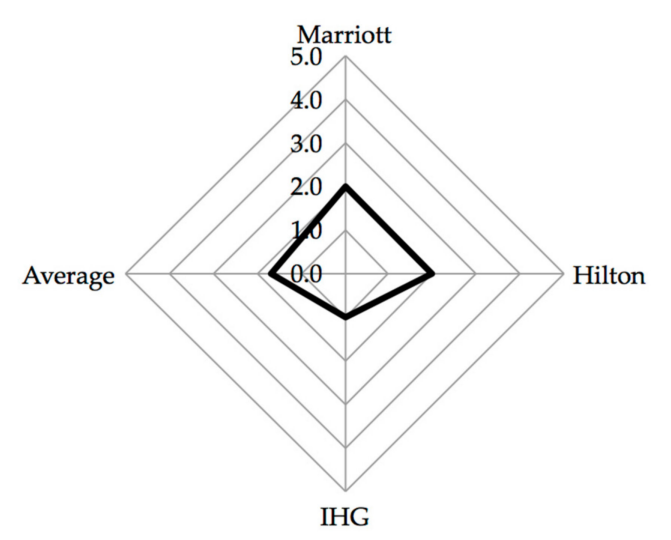

Figure 6. Maturity scores from metric analysis of the hotel and lodging companies.

\section{Discussion}

Tourism destination economies are largely dependent on the success of the hospitality and tourism sector [24]. The hotel and lodging industry in particular are hubs for more than their own typical activities; these properties are also hubs for all of the community activities that promote the overall community's recovery and resilience [13].

The literature review at the property level revealed that hotels are currently contributing to disaster preparedness, response, and recovery in a variety of ways, providing financial contributions, donating commercial products and services, deploying employees, and building community capital. These properties are hubs for community resilience, providing both lifeline services and leveraging their core skills and competencies to aid in disaster recovery $[9,10,14,20-22,33-83]$. 
Unlike other critical infrastructures, hotel and lodging properties provide all of the lifeline services with the exception of healthcare. In many cases, hotel and lodging properties often shelter healthcare workers, and may even establish a temporary healthcare center for employees. Hotel and lodging properties also in many cases provide these services to non-resident community members. The extent of hotel and lodging property capabilities is unique from other critical infrastructures, providing the industry with an opportunity to act as a leader in community disaster relief and resilience.

However, an examination of corporate-level management systems would suggest that hotels' contributions lack integration and are still very immature overall. The link between CSR and disaster management is fairly new, which is likely why this area of CSR management remains a significant opportunity for growth. In order to strengthen the disaster resilience of the collective system, hotel and lodging companies must develop more mature management systems at the corporate level to better coordinate efforts, and account appropriately for their efforts.

While properties may have more actions at the local level, coordination and management requires strong direction at the corporate level. Further, if a corporate goal is published externally, there is increased pressure by external stakeholders for the company to achieve improvements in performance. Thus, these goals tend to be achieved more rapidly [91]. CSR goals also demonstrate top management commitment and set the precedent for properties to allocate resources to related activities, thereby driving improvement in performance at the property level [6,92].

The hotel and lodging industry may want to look to other sectors and related industries to identify additional ways that it can contribute to disaster relief and resilience. For example, Airbnb is not a luxury hotel, but it possesses similar capabilities to a hotel. Airbnb disaster initiatives are more grassroots, and in order for hotels to develop more locality-specific solutions, it may be helpful to look to the more grassroots initiatives to inform their initiatives. During Hurricane Harvey, Airbnb used its application to place affected community members in need of shelter with people willing to provide free accommodation [33].

Perhaps similar software could be developed for hotels to post available rooms and coordinate the placement of affected community members across their properties. Some hotels hold fundraisers where customers can donate loyalty points to provide rooms for people affected by disasters. The software could help place affected community members in these donated rooms. Also, the application could include information about disaster policies, such as properties that allow pets or discounted pet rates during disasters, to help improve speed and ease of placement.

Additionally, application of the metric sets to management system development and implementation will also be useful in improving hotel and lodging corporations' CSR management for disaster relief and resilience. Using laddered metrics to evaluate performance is the first step toward improving the performance of the collective system, providing a baseline and a roadmap for companies to improve management system maturity $[26,86]$. The literature review suggests that it is likely that these companies' properties are engaging in these activities, but the companies may not manage these activities at the corporate level or have effective systems in place for evaluating performance and driving continual improvement.

The quantitative measurement of social impacts is also essential for understanding the criticality of the hotel and lodging industry to disaster relief and resilience, which may be undervalued in destination disaster resilience. The hotel and lodging industry is unique from other types of critical infrastructures. Unlike most critical infrastructures, the hotel and lodging industry is a service industry, and their core skills and competencies are largely types of social and human capital. Thus, building human capital within operations through professional education and training is essential for operational resilience and enabling the hotel and lodging corporations to affect community resilience.

As companies begin to track more proxy metrics to evaluate the social impacts of their contributions, economic value can be assigned to the impacts. Determining the economic value of these contributions is useful for understanding the criticality of the hotel and lodging industry to 
community disaster resilience. If hotels truly are hubs for community resilience, then the community should prioritize the DRR lifeline services in these locations to best aid community recovery.

Additionally, quantifying social impacts allows the industry to evaluate whether they should contribute more to community disaster resilience in the future [93]. Once economic value is assigned to the benefits of social and human capital creation, an SROI calculation can be performed. If the SROI is greater than one, then the company is contributing an amount to disaster resilience that provides more social benefit to the collective community-organizational system than it costs the organization.

Community and organizational resilience are interdependent, and, thus, contributions to community resilience also improve organizational resilience [89]. However, organizations must best allocate limited resources, so it is essential for organizations to maximize social value creation. The measurement of social value creation by contributions is needed not only to quantify the contributions of the industry and understand its criticality to destination resilience, but also to further the understanding of disaster recovery itself.

The resurgence of the hotel and lodging industry may also act as an indicator for broader community recovery [93]. Fundamentally, destination community resilience depends on the hotel and lodging industry's engagement and resilience. The transition of hotel and lodging properties from acting as a transitional shelter for community members and responders to hosting vacationing visitors signals that permanent housing and infrastructure has been recovered at the community scale. Additionally, if hotels have begun to host visitors, then other hospitality and tourism industries will begin to have customers again, supporting the economic recovery of the community as a whole. Figure 7 demonstrates the overlap between the sustainable development and disaster management of the collective community-organizational system, showing how hotels contribute to destination disaster relief and resilience.

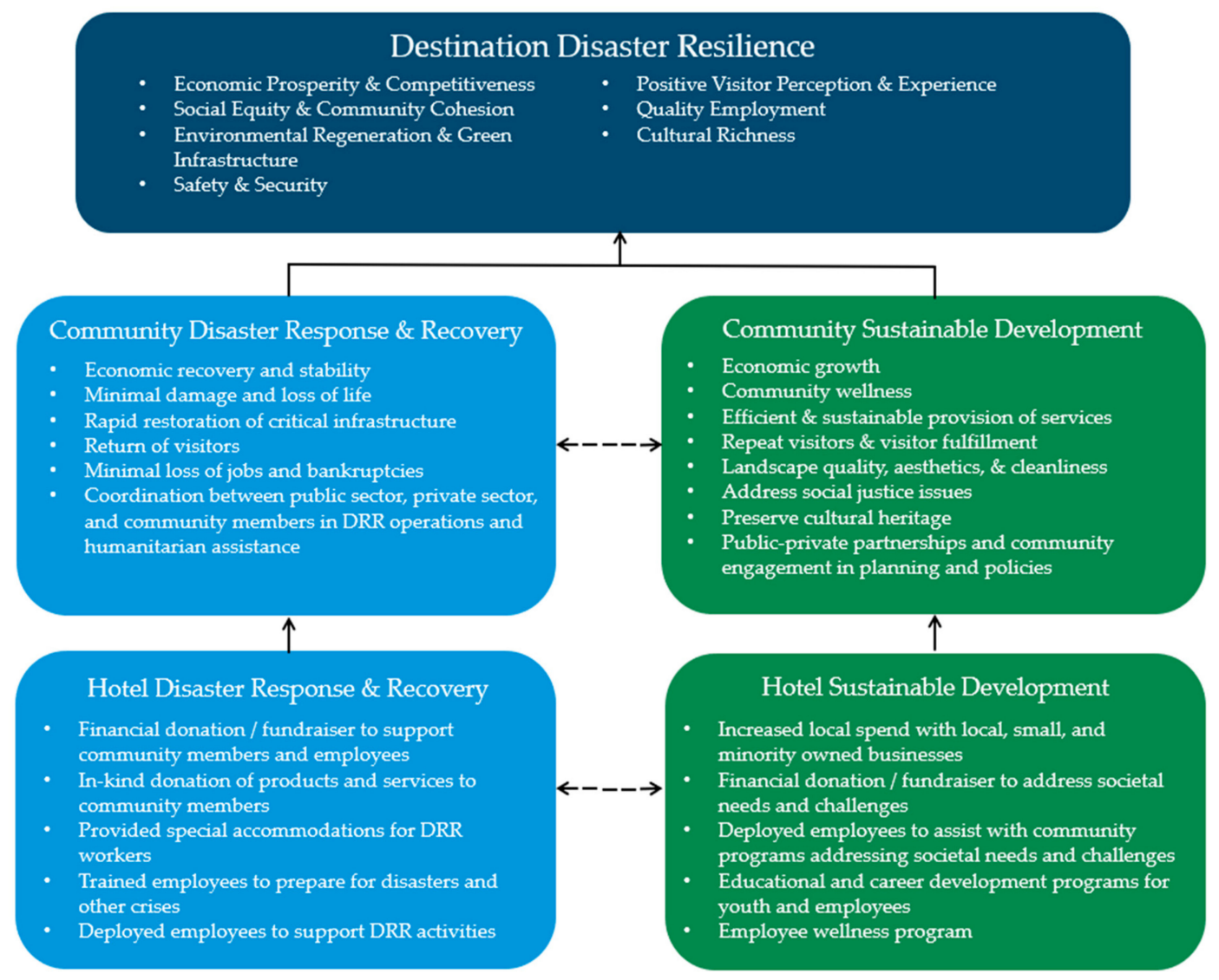

Figure 7. Demonstrating the convergence between disaster relief and sustainable development for destination resilience, as well as the relationship between community and hotel management. 


\section{Conclusions}

The hotel and lodging industry has contributed to disaster relief and resilience at the property level by leveraging their core skills and competencies. The three hotel and lodging companies examined received a 1.5 maturity score for the vision/policy statement and goal analysis, and a 1.4 maturity score for the metric analysis. These analyses revealed that corporate CSR reporting for disaster relief and resilience is currently primarily focused on making financial contributions to disaster relief. Companies have also begun proactively contributing to community capital, but there is a major gap in reporting of CSR activities, particularly after a crisis.

Corporate management systems are failing to account for the opportunity to apply core skills and competencies to support and enhance community disaster relief and resilience. It is likely that these companies' properties are engaging in these activities at the property level, but corporate-level CSR management systems do not yet formally support, measure, and manage these activities, which limits the hotel sector and lodging sector's potential contributions.

Top management commitment and vision is the first step in driving continuous improvement via a management system [94]. Until these companies drive the application of the hotel and lodging industry's core skills and competencies, the industry may not reach its full potential to contribute to destination resilience and their overall business health in crisis times, as hotels and destination communities have linked goals.

Given that the hotel and lodging industry is a critical infrastructure that provides nearly all of the lifeline services during a disaster and possesses social and human capital that allows the industry to enhance community disaster recovery, it is essential to develop a method to value these contributions at the local and corporate levels. Measuring the industry's contribution to disaster preparedness, response, and recovery can help understandings of the criticality of the industry. Additionally, these companies can begin to derive the economic value of the social impacts of their contributions to understand the social return on their investments in disaster relief. Future work should examine cases that apply SROI to assess disaster relief and resilience activities.

Author Contributions: Conceptualization, S.D. and J.S.; Methodology, S.D. and J.S.; Validation, S.D. and J.S.; Formal Analysis, S.D.; Investigation, S.D.; Data Curation, S.D.; Writing-Original Draft Preparation, S.D.; Writing-Review \& Editing, J.S., M.K. and R.L.; Visualization, S.D.; Supervision, J.S., M.K. and R.L.; Project Administration, S.D.; Funding Acquisition, J.S., M.K. and R.L.

Funding: This material is based upon work partially supported by the ADVANCE RIT grant which is funded through the National Science Foundation under Award No. HRD-1209115, as well as work partially supported by Award 70NANB16H268 from the National Institute of Standards and Technology.

Conflicts of Interest: The authors declare no conflict of interest. The funders had no role in the design of the study; in the collection, analyses, or interpretation of data; in the writing of the manuscript, and in the decision to publish the results.

\section{References}

1. Intergovernmental Panel on Climate Change. Available online: https://www.ipcc.ch/pdf/special-reports/ srex/SREX_Full_Report.pdf (accessed on 20 July 2018).

2. United States Environmental Protection Agency. Available online: https://www.epa.gov/ghgemissions/ endangerment-and-cause-or-contribute-findings-greenhouse-gases-under-section-202a-clean (accessed on 20 July 2018).

3. National Oceanic and Atmospheric Administration. Available online: https://www.ncdc.noaa.gov/billions/ (accessed on 20 July 2018).

4. Community and Regional Resilience Institute (CARRI). Available online: http:/ /www.resilientus.org/wpcontent/uploads / 2013/08/definitions-of-community-resilience.pdf (accessed on 17 June 2018).

5. 100 Resilient Cities. Available online: https://www.100resilientcities.org/ (accessed on 10 August 2018).

6. International Organization for Standardization. Available online: https://www.iso.org/publication/ PUB100394.html (accessed on 28 July 2018). 
7. Callaghan, E.G.; Colton, J. Building sustainable \& resilient communities: a balancing of community capital. Environ. Dev. Sustain. 2008, 10, 931-942. [CrossRef]

8. Woolcock, M. The place of social capital in understanding social and economic outcomes. Can. J. Policy Res. 2001, 2, 11-17.

9. Business in the Community. Available online: https://www.bitc.org.uk/system/files/international_ disaster_relief_septmber_2014.pdf (accessed on 28 July 2018).

10. Business in the Community. Available online: https://www.bitc.org.uk/sites/default/files/business_ unique_contribution_ii.pdf (accessed on 28 July 2018).

11. Caribbean Tourism Organization. Available online: https://www.onecaribbean.org/wp-content/uploads/ Disaster-Risk-Management-Coastal-Tourism-UNEP-CAST.pdf (accessed on 20 July 2018).

12. Bunghez, C.L. The importance of tourism to a destination's economy. J. East. Eur. Res. Bus. Econ. 2016, 1-9. [CrossRef]

13. Becken, S.; Khazi, B. Resilience, tourism and disasters. In Tourism and Resilience; Butler, R.W., Ed.; CAB International: Boston, MA, USA, 2017; pp. 96-102.

14. Johnson, B.R.; Connolly, E.; Carter, T.S. Corporate social responsibility: The role of fortune 100 companies in domestic and international natural disasters. Corp. Soc. Responsib. Environ. Manag. 2011, 18, 352-369. [CrossRef]

15. Dahlsrud, A. How corporate social responsibility is defined: An analysis of 37 definitions. Corp. Soc. Responsib. Environ. Manag. 2008, 15, 1-13. [CrossRef]

16. European Commission. Available online: http://ec.europa.eu/transparency/regdoc/rep/1/2001/EN/12001-366-EN-1-0.Pdf (accessed on 20 July 2018).

17. Carroll, A.B. The four faces of corporate citizenship. Bus. Soc. Rev. 1998, 100, 1-7. [CrossRef]

18. Carroll, A.B. A history of corporate social responsibility: Concepts and practices. In The Oxford Handbook of Corporate Social Responsibility; Crane, A., Matten, D., McWillianms, A., Moon, J., Siegel, D.S., Eds.; Oxford University Press: Oxford, UK, 2008; pp. 19-46.

19. Collier, P. Social capital and poverty: A microeconomic perspective. In The Role of Social Capital in Development: An Empirical Assessment; Crane, A., McWilliams, A., Matten, D., Moon, J., Siegel, D.S., Eds.; Oxford University Press: Oxford, UK, 2002; pp. 19-41.

20. UN-Business Action Hub. Available online: https://business.un.org/en/documents/257 (accessed on 28 July 2018).

21. Connecting Business Initiative. Available online: https://www.connectingbusiness.org/system/files/201712/PSS-BusinessCase-FINAL.pdf (accessed on 28 July 2018).

22. Marriott International. Available online: http://serve360.marriott.com/wp-content/uploads/2017/10/ 2017_Sustainability_and_Social_Impact_Highlights.pdf (accessed on 28 July 2018).

23. Hilton. Available online: https://cr.hilton.com/wp-content/uploads/2018/05/Hilton_Infograph_2030_ Value-Chain-Targets.pdf (accessed on 28 July 2018).

24. Henderson, J.C. Corporate social responsibility and tourism: Hotel companies in Phuket, Thailand, after the Indian Ocean tsunami. Int. J. Hosp. Manag. 2007, 26, 228-239. [CrossRef]

25. Velva, V.; Ellenbecker, M. Indicators of sustainable production: framework and methodology. J. Clean. Prod. 2001, 9, 519-549. [CrossRef]

26. Dobie, S.; Schneider, J. Development of a process improvement matrix to measure community level sustainability and resilience: A collaborative case study of Rochester, NY, USA. In Proceedings of the 2017 IEEE Symposium on Technologies for Homeland Security (HST), Waltham, MA, USA, 25-26 April 2017; pp. 1-5. [CrossRef]

27. Larsson, M.; Milestad, R.; Hahn, T.; von Oelreich, J. The resilience of a sustainability entrepreneur in the Swedish food system. Sustainability 2016, 8, 550. [CrossRef]

28. Harvard Business Review. Available online: https://hbr.org/2011/01/the-big-idea-creating-shared-value./ (accessed on 20 July 2018).

29. Social Value UK. Available online: http:/ / www.socialvalueuk.org/app/uploads/2016/03/The\%20Guide\% 20to\%20Social\%20Return\%20on\%20Investment\%202015.pdf (accessed on 20 July 2018).

30. World Bank. Available online: http://siteresources.worldbank.org/INTSOCIALCAPITAL/Resources/ Social-Capital-Initiative-Working-Paper-Series/SCI-WPS-24.pdf (accessed on 20 July 2018). 
31. World Bank. Available online: http://documents.worldbank.org/curated/en/550171468338972685/ Measuring-impact-framework-methodology-understanding-the-business-contribution-to-society (accessed on 20 July 2018).

32. Babson College. Available online: https://www.babson.edu/Academics/centers/the-lewis-institute/ SiteAssets / Pages / Business-and-Social-Innovation-Intensity-Track/Corporate\%20Social\%20Innovation\% 20Mirvis\%20Googins\%20Kiser_classroom\%20use.pdf (accessed on 20 July 2018).

33. Airbnb, Inc. Available online: https://www.airbnb.com/welcome/evacuees/hurricaneharveyevacuees (accessed on 28 July 2018).

34. Conde Nast Traveler. Available online: https://www.cntraveler.com/stories/2013-10-29/hotels-that-helpedduring-hurricane-sandy (accessed on 28 July 2018).

35. Conrad N. Hilton Foundation. Available online: https://www.hiltonfoundation.org/grants?priority=disasterrelief-and-recovery\#filters (accessed on 28 July 2018).

36. Due South Brewing Company. Available online: https://www.duesouthbrewing.com/2017/09/06/hurricaneirma-free-water-fills / (accessed on 28 July 2018).

37. Eyewitness News. Available online: http://abc13.com/community-events/southern-smoke-brings-reliefto-harvey-victims / 2527338 / (accessed on 28 July 2018).

38. Florida Restaurant and Lodging Association. Available online: https://frla.org/frla-gives-back/ (accessed on 28 July 2018).

39. Gamit. Available online: https://www.bestofneworleans.com/gambit/new-orleans-restaurants-raisemoney-for-harvey-and-irma-victims/Content?oid=6860293 (accessed on 28 July 2018).

40. Harvard Business Review. Available online: https://hbr.org/2006/11/disaster-relief-inc (accessed on 28 July 2018).

41. Haute Living. Available online: http://hauteliving.com/2017/09/miami-hotels-and-restaurants-offerspecial-deals-and-relief-funds-for-irma/643131/ (accessed on 28 July 2018).

42. Hilton. Available online: https://hiltonresponds.charity.org/campaigns/ (accessed on 28 July 2018).

43. Hotel News Resource. Available online: https://www.hotelnewsresource.com/article1175Hyatt_Partners_ With_American_Red_Cross_for_the_Fourth_Annual_Hyatt_s_Drive_for_Life.html (accessed on 28 July 2018).

44. Hotel News Resource. Available online: https://www.hotelnewsresource.com/article15427.html (accessed on 28 July 2018).

45. Hotel News Resource. Available online: https://www.hotelnewsresource.com/article18509.html (accessed on 28 July 2018).

46. Hotel News Resource Mobile Edition. Available online: https://mobi.hotelnewsresource.com/?p=74094 (accessed on 28 July 2018).

47. Hotel News Resource. Available online: https://www.hotelnewsresource.com/article85252.html (accessed on 28 July 2018).

48. Hotel News Resource. Available online: https://www.hotelnewsresource.com/article99950.html (accessed on 28 July 2018).

49. Hyatt Thrive. Available online: https://thrive.hyatt.com/content/dam/Minisites/hyattthrive/reports / Communities-2015.pdf (accessed on 28 July 2018).

50. Institute of Medicine. Healthy, Resilient, and Sustainable Communities After Disasters: Strategies, Opportunities, and Planning for Recovery; The National Academies Press: Washington, DC, USA, 2015. [CrossRef]

51. Intercontinental Hotel Group Foundation. Available online: http://www.ihgfoundation.org/en-us / our-stories / (accessed on 28 July 2018).

52. Mandarin Oriental. Available online: http://photos.mandarinoriental.com/is/content/MandarinOriental/ mandarin-oriental-sustainability-report-2016?_ga=2.138339696.1306790186.1521037678-2120341125. 1521037678 (accessed on 28 July 2018).

53. Marriott International. Available online: https://cfncr.wufoo.com/forms/z3oj6p1kavwo3/ (accessed on 28 July 2018).

54. Marriott International. Available online: https://www.marriott.com/culture-and-values/takecare-relief-fund.mi (accessed on 28 July 2018).

55. Marriott International. Available online: https://marriottinternationalinc.childrensmiraclenetworkhospitals.org/ (accessed on 28 July 2018).

56. Marriott International. Available online: http://stories.marriott.com/ (accessed on 28 July 2018). 
57. Medium. Available online: https://medium.com/@StarwoodHotels/making-progress-on-our-internalstarwood-associate-relief-fund-goals-a8c502ea023b (accessed on 28 July 2018).

58. Miami New Times. Available online: http://www.miaminewtimes.com/restaurants/islamorada-beercompany-drives-hurricane-irma-relief-efforts-in-the-florida-keys-9699112 (accessed on 28 July 2018).

59. Nation's Restaurant News. Available online: http://www.nrn.com/family-dining/denny-s-mobilekitchen-offers-pancakes-and-comfort-hurricane-victims?NL=NRN-02_\&Issue=NRN-02_20170926_

NRN-02_141\&sfvc4enews=42\&cl=article_1_2\&utm_rid=CPG06000001198841\&utm_campaign=19067\& utm_medium=email\&elq2=9110e91e0ebe42c0b1805ffe9d35e410 (accessed on 28 July 2018).

60. News-Press. Available online: https://www.news-press.com/story/life/food/2017/09/18/hurricaneirma-food-florida-chefs-and-restaurants-give-generously-before-and-after-storm/667597001/ (accessed on 28 July 2018).

61. Orlando Sentinel. Available online: http://www.orlandosentinel.com/weather/hurricane/os-hurricaneirma-disney-orlando-travel-20170905-story.html (accessed on 28 July 2018).

62. Silicon Valley Community Foundation. Available online: https://www.siliconvalleycf.org/sites/default/ files/documents/csr/SVCF_CorporateDisasterResponseGuide_web.pdf (accessed on 28 July 2018).

63. Starwood Hotels and Resorts. Available online: https://www.starwoodhotels.com/Media/PDF/Corporate/ GC_Report_2014.pdf (accessed on 28 July 2018).

64. Sun Sentinel. Available online: http:/ / www.sun-sentinel.com/features/deals-shopping/sfl-free-meals-forfirst-responders-at-mcdonald-s-on-wednesday-20170924-story.html (accessed on 28 July 2018).

65. Tampa Bay Online. Available online: http://www.tbo.com/news/weather/hurricanes/critical-need-afterthe-storm-feeding-those-in-need/2337132 (accessed on 28 July 2018).

66. Tech Crunch. Available online: https://techcrunch.com/2017/08/29/tech-companies-harvey-houston-fundraising/ (accessed on 28 July 2018).

67. The Coca-Cola Company. Available online: http://www.coca-colacompany.com/stories/2016-giving-back (accessed on 28 July 2018).

68. The Dodo. Available online: https://www.thedodo.com/close-to-home/orlando-hotel-welcomes-900-dogshurricane-irma (accessed on 28 July 2018).

69. The Hongkong and Shanghai Hotels, Limited. Available online: https://www.hshgroup.com/-/media/ Files/HSH/Sustainability-Reports/2016-Sustainability-Report_EN.ashx (accessed on 28 July 2018).

70. The Points Guy. Available online: https://thepointsguy.com/2017/11/new-caribbean-hotels-storm-relief-efforts/ (accessed on 28 July 2018).

71. The Rezidor Hotel Group. Available online: https://www.radissonhospitalityab.com/encrypt/files? file=nasdaq_kms / assets /2018/04/05/7-39-26/The\%20Rezidor\%20Hotel\%20Group_Responsible\% 20Business\%20Report_Annual\%20Report\%202017.pdf\&file_alias=9181 (accessed on 28 July 2018).

72. Tourism Cares. Available online: https://static1.squarespace.com/static/54de6549e4b054179782b0eb/t/ 550c3a85e4b082f6eb126c13/1426864773852/2014impactreports.pdf (accessed on 28 July 2018).

73. Tourism Cares. Available online: https://static1.squarespace.com/static/54de6549e4b054179782b0eb/t/ 579b5fd29de4bb9f9ba85b09/1469800408788/Minneapolis_ImpactReport.pdf (accessed on 28 July 2018).

74. Tourism Cares. Available online: https:/ / static1.squarespace.com/static/54de6549e4b054179782b0eb/t/ 57eab32c197aea92a6ba375b/1474999088365/MountRainierImpactReport.pdf (accessed on 28 July 2018).

75. Tourism Cares. Available online: https://static1.squarespace.com/static/54de6549e4b054179782b0eb/t/ 5820ce4046c3c40f06281954/1478544985897/NYCImpactReport.pdf (accessed on 28 July 2018).

76. Tourism Cares. Available online: http://www.wyndhamworldwide.com/category/corporate-socialresponsibility-report (accessed on 28 July 2018).

77. Tourism Cares for Our Cities. Available online: https://static1.squarespace.com/static/ 54de6549e4b054179782b0eb/t/59fcb0618e7b0fb056b2163f/1509732486671/TotalImpactReport.pdf (accessed on 28 July 2018).

78. Tourism Cares for South Florida. Available online: https://static1.squarespace.com/static/ 54de6549e4b054179782b0eb/t/5afc6b68758d46ea24f2737c/1526492021623/SoFla_ImpactReport_digital.pdf (accessed on 28 July 2018).

79. Tourism Cares. Available online: https:/ / us9.campaign-archive.com/?u=04561ca932ae66d0655b11236\&id= 95ff9340f3 (accessed on 28 July 2018). 
80. Twigg, J. Corporate Social Responsibility and Disaster Reduction: A Global Overview. Available online: https:/ /assets. publishing.service.gov.uk/media/57a08d66ed915d3cfd0019e8/R7893CSROverview.pdf (accessed on 28 July 2018).

81. United Parcel Service of America, Inc. Available online: https://sustainability.ups.com/media/2016_UPS_CSR.pdf (accessed on 28 July 2018).

82. USA Today. Available online: https:/ / www.usatoday.com/story/travel/roadwarriorvoices/2017/09/22/ hotels-respond-series-hurricanes / 692325001/ (accessed on 28 July 2018).

83. Wyndham Destinations. Available online: http://www2.wyndhamdestinations.com/category/corporatesocial-responsibility (accessed on 28 July 2018).

84. Dobie, S.; Schneider, J. Measuring the impact of organizational efforts on community sustainability and resilience. In Proceedings of the AWMA Finding Common Ground on Climate Change Mitigation and Adaptation, Arlington, VA, USA, 10-11 October 2017.

85. Schneider, J.; Romanowski, C.J.; Raj, R.K.; Mishra, S.; Stein, K. Measurement of locality specific resilience. In Proceedings of the 2015 IEEE International Conference on Technologies for Homeland Security (HST), Waltham, MA, USA, 14-16 April 2015. [CrossRef]

86. Schneider, J.; Romanowski, C.J.; Mishra, S.; Raj, R.K.; McGuinness, M.; Swartz, B. Building forward: strategic community resilience. In Proceedings of the 2017 IEEE International Conference on Technologies for Homeland Security (HST), Waltham, MA, USA, 25-26 April 2017. [CrossRef]

87. Wachter, J.K.; Yorio, P.L. A system of safety management practices and worker engagement for reducing and preventing accidents: An empirical and theoretical investigation. Accid. Anal. Prev. 2014, 68, 117-130. [CrossRef] [PubMed]

88. Hotel News Now. Available online: http://hotelnewsnow.com/Articles/115537/Updated-infographicLook-at-hotel-industrys-largest (accessed on 20 July 2018).

89. Lee, A.; Vargo, J.; Seville, E. Developing a Tool to Measure and Compare Organizations' Resilience. Nat. Hazards Rev. 2013, 14, 29-41. [CrossRef]

90. Romanowski, C.; Schneider, J. Critical infrastructure protection and risk analysis in the mid-size city. In Proceedings of the IEEE 2012 Conference for Technologies for Homeland Security (HST), Waltham, MA, USA, 13-15 November 2012. [CrossRef]

91. Carbon Disclosure Project. Available online: https://www.cdp.net/en/articles/companies/top-challengesfor-businesses-setting-goals-around-climate-change (accessed on 30 July 2018).

92. Efficient Plant. Available online: https://www.efficientplantmag.com/2008/06/driving-operationalimprovements-through-strategic-alignment/ (accessed on 30 July 2018).

93. Dobie, S.; Schneider, J.; Kesgin, M.; Lagiewski, R. Critical hospitality: Metrics as a path to resort resilience. In Proceedings of the 2018 International Symposium on Sustainable Systems and Technologies, Buffalo, NY, USA, 26-28 June 2017; Accepted.

94. Schneider, J.; Romanowski, C.J.; Raj, R.K.; Mishra, S.; Aleckna, J.; Wang, K. Mapping a community resilience management system: building operational knowledge. In Proceedings of the 2016 IEEE International Conference on Technologies for Homeland Security (HST), Waltham, MA, USA, 10-11 April 2016. [CrossRef]

(c) 2018 by the authors. Licensee MDPI, Basel, Switzerland. This article is an open access article distributed under the terms and conditions of the Creative Commons Attribution (CC BY) license (http:/ / creativecommons.org/licenses/by/4.0/). 